\title{
EFFECT OF UREA WITH NUTRISPHERE-N POLYMER IN FALL AND SPRING NITROGEN APPLICATIONS FOR CORN
}

\author{
${ }^{1}$ Pawel Wiatrak and ${ }^{2}$ Walter B. Gordon \\ ${ }^{1}$ School of Agricultural, \\ Forest and Environmental Sciences, Clemson University, Edisto REC, Blackville, USA \\ ${ }^{2}$ Department of Agronomy, Kansas State University, Manhattan, Kansas, USA
}

Received 2013-12-11; Revised 2013-12-22; Accepted 2013-12-27

\begin{abstract}
Polymer coated urea may be a viable option to improve Nitrogen $(\mathrm{N})$ uptake and corn (Zea mays L.) grain yields, especially in areas with relatively high soil $\mathrm{N}$ loss. The objective of this study was to evaluate the effect of two urea application timings (fall and spring) and three $\mathrm{N}$ rates $\left(90,180\right.$ and $270 \mathrm{~kg} \mathrm{~N} \mathrm{ha}^{-1}$ ) with and without Nutrisphere-N polymer on irrigated corn near Scandia, KS from 2006 to 2008. Compared to uncoated $\mathrm{N}$, urea coated with Nutrisphere-N improved grain yields by $18.3 \%$ with applications of $180 \mathrm{~kg} \mathrm{~N} \mathrm{ha}^{-1}$ in the fall. Application of urea with Nutrisphere- $\mathrm{N}$ in the spring produced similar grain yields for treatments with and without Nutrisphere-N. Corn ear-leaf content was highest with urea applied at $90 \mathrm{~kg} \mathrm{~N} \mathrm{ha}^{-1}$ in the fall and urea coated with Nutrisphere- $\mathrm{N}$ at 180 and $240 \mathrm{~kg} \mathrm{~N} \mathrm{ha}^{-1}$ in the fall and spring. Grain N content was highest from urea coated with Nutrisphere- $\mathrm{N}$ application at $270 \mathrm{~kg} \mathrm{~N} \mathrm{ha}^{-1}$ in the fall and spring. Compared to untreated urea, Nutrisphere- $\mathrm{N}$ improved grain $\mathrm{N}$ removal by $29.6 \%$ at $180 \mathrm{~kg} \mathrm{~N}^{-1}$ applied in the fall. Spring urea application with Nutrisphere- $\mathrm{N}$ produced similar grain $\mathrm{N}$ removal compared to urea without Nutrisphere- $\mathrm{N}$. Generally, adding Nutrisphere- $\mathrm{N}$ to urea fertilizer may help improve $\mathrm{N}$ content in leaves and grain and increase grain yields of corn, especially with the fall $\mathrm{N}$ applications having higher potential of soil $\mathrm{N}$ loss.
\end{abstract}

Keywords: Corn, Polymer, Nutrisphere-N, Urea

\section{INTRODUCTION}

Fertilizer usage is high to support crop production for a growing world population ( $\mathrm{Ni}$ et al., 2011). Hubbard et al. (2004) noted that high nitrate-N concentrations in soil and groundwater may lead to health problems in humans and animals. The need for greater crop productivity and higher yield effects on production costs per unit of yield coupled with maximizing return on capital invested in $\mathrm{N}$ fertilizer as well as environmental concerns are driving crop producers to evaluate practices, which improve $\mathrm{N}$ use efficiency (Shaviv, 2005). Shaviv (2005) also emphasized the importance of synchronizing plant N demand and supply. Spargo et al. (2011) noted that sustainable crop production should include optimal utilization of mineralizable $\mathrm{N}$ from soil organic matter as well as carry-over $\mathrm{N}$ from previous crops.
Fertilizer recommendations depend on evaluation of supplied and immobilized nutrients in the soil, which are especially important for site-specific management of nutrients (Anthony et al., 2012). Key factors in improving $\mathrm{N}$ use efficiency and uptake are nitrification and ammonia volatilization (Mortvedt et al., 1999). Hubbard et al. (2004) reported that leaching of $\mathrm{NO}_{3}-\mathrm{N}$ and $\mathrm{NO}_{2}-\mathrm{N}$ to groundwater is a problem in the southeastern Coastal Plain of the United States (US) due to relatively high rainfall.

Optimized irrigation and $\mathrm{N}$ fertilization practices can help to minimize $\mathrm{NO}_{3}-\mathrm{N}$ leaching below the root zone, improve $\mathrm{N}$ uptake and increase crop yield (MartinezAlcantara et al., 2012). Additional options to improve $\mathrm{N}$ efficiency include splitting $\mathrm{N}$ applications, nitrification and urease inhibitors and using slow release fertilizers (Shaviv, 2005). Cahill et al. (2010) added that alternative

Corresponding Author: Pawel Wiatrak, School of Agricultural, Forest and Environmental Sciences, Clemson University, Edisto REC, Blackville, USA 
$\mathrm{N}$ fertilizers may help to decrease volatilization, improve $\mathrm{N}$ use efficiency and increase crop yields. Slow-release fertilizers with good water-retention properties would be environmentally friendly due to reduction of nutrient loss and improved efficiency (Ni et al., 2009).

Kyveryga et al. (2013) noted that current $\mathrm{N}$ recommendations for corn do not fully quantify factors, which affect yield response to $\mathrm{N}$. Urea coated with various materials, including a dicarboxylic co-polymer (Nutrisphere- $\mathrm{N} \circledast$ ), may be a good $\mathrm{N}$ management option, because of nitrification and urea volatilization inhibiting properties (Gordon, 2008). However, growers need to evaluate the use of alternative $\mathrm{N}$ fertilizer under different climatic conditions and locations (Cahill et al., 2010). Therefore, the objective of this study was to evaluate the effect of two urea application timings (fall and spring) and three $\mathrm{N}$ rates $\left(90,180\right.$ and $270 \mathrm{~kg} \mathrm{~N} \mathrm{ha}^{-1}$ ) with Nutrisphere-N polymer on irrigated corn in the Great Plains region of the US.

\section{MATERIALS AND METHODS}

\subsection{Site Preparation and Management}

This experiment was conducted on Crete silt loam soil (Fine, smectitic, mesic Pachic Udertic Argiustolls) at North Central Kansas Experiment Field, Kansas State University, located near Scandia, KS under irrigated conditions from 2006 to 2008. The soil $\mathrm{pH}$ was 7.0, organic matter content was $2.8 \%$, Bray-1 P was 28 ppm and exchangeable potassium (K) was $240 \mathrm{ppm}$.

Corn cv. 'DeKalb DKC60-19' was planted following previous corn crop at 76,570 seeds $\mathrm{ha}^{-1}$ in no-till on 20 , 22 and 19 April in 2006, 2007 and 2008, respectively. Nitrogen treatments consisted of uncoated urea and urea coated with Nutrisphere-N (2.1 $\left.11000 \mathrm{~kg}^{-1}\right)$ applied in the fall/winter January 2006 and November in 2007 and 2008 , respectively) and in the spring (following planting) and three $\mathrm{N}$ rates $\left(90,180\right.$ and $\left.270 \mathrm{~kg} \mathrm{~N} \mathrm{ha}^{-1}\right)$.

Weed control was based on the Kansas State University Extension recommendations.

\subsection{Plant Measurements}

Plant measurements were conducted in the center of each plot. Corn ear-leaf samples for $\mathrm{N}$ content were collected at R1 stage. Corn was harvested using small grain plot combine on 20 October 2006, 10 October 2007 and 18 October 2008. Grain samples from all harvested plots were evaluated for moisture content. Corn grain yields were corrected to $155 \mathrm{~g} \mathrm{~kg}^{-1}$ moisture content. Additionally, grain samples were evaluated for $\mathrm{N}$ content. The $\mathrm{N}$ removal (recovery) was calculated based on grain $\mathrm{N}$ content and yields.

\subsection{Statistical Analysis}

The study design was a randomized complete block with four replications. Data were analyzed using the general linear models (SAS, 2011) and means for grain yields and $\mathrm{N}$ removal were shown by $\mathrm{N}$ application timings.

\section{RESULTS}

\subsection{Corn Ear-Leaf and Grain N Content}

Corn ear-leaf was highest for treatments with urea at $90 \mathrm{~kg} \mathrm{~N} \mathrm{ha}^{-1}$ and urea with Nutrisphere-N applied at 180 and $270 \mathrm{~kg} \mathrm{~N} \mathrm{ha}^{-1}$ (Table 1). Compared to uncoated N, urea coated with Nutrisphere- $\mathrm{N}$ improved corn ear-leaf content by $16.2 \%$ and $14.4 \%$ at $180 \mathrm{~kg}$ and $270 \mathrm{~kg} \mathrm{~N}$ $\mathrm{ha}^{-1}$ for the fall applied $\mathrm{N}$ and $24.8 \%, 11.8 \%$ and $11.9 \%$ with applications of $90 \mathrm{~kg}, 180 \mathrm{~kg}$ and $270 \mathrm{~kg} \mathrm{~N} \mathrm{ha}^{-1}$ for spring applied $\mathrm{N}$, respectively. Averaged across $\mathrm{N}$ rates, urea coated with Nutrisphere-N increased ear-leaf $\mathrm{N}$ content by $8.7 \%$ with fall application and $16.2 \%$ with spring application of $\mathrm{N}$.

Highest grain $\mathrm{N}$ was recorded with application of urea coated with Nutrisphere-N at $270 \mathrm{~kg} \mathrm{~N} \mathrm{ha}^{-1}$ in the fall and spring (Table 1). Grain $\mathrm{N}$ improved with Nutrisphere-N application by $4.1 \%, 9.5 \%$ and $7.5 \%$ for fall applications and $6.6 \%, 8.7 \%$ and $6.0 \%$ over untreated control at $90 \mathrm{~kg}, 180 \mathrm{~kg}$ and $270 \mathrm{~kg} \mathrm{~N}^{-1}$ applied in the spring, respectively. Grain $\mathrm{N}$ improved on average by at least $7 \%$ with fall and spring $\mathrm{N}$ applications using urea coated with Nutrisphere-N compared to uncoated urea.

Table 1. Influence of urea with and without Nutrisphere-N applied in the fall and spring on ear-leaf and grain $\mathrm{N}$ of corn

\begin{tabular}{lcll}
\hline \multicolumn{1}{c}{ N of corn } & & \\
Treatment & $\begin{array}{c}\mathrm{N} \text { rate } \\
\left(\mathrm{kg} \mathrm{ha}^{-1}\right)\end{array}$ & $\begin{array}{l}\text { Ear-leaf } \\
\mathrm{N} \%\end{array}$ & $\begin{array}{l}\text { Grain } \\
\mathrm{N} \%\end{array}$ \\
\hline Control & 0 & 1.67 & 1.12 \\
Fall applied N & & & \\
Urea & 90 & 2.95 & 1.22 \\
Urea & 180 & 2.53 & 1.26 \\
Urea & 270 & 2.63 & 1.34 \\
Urea with Nutrisphere-N & 90 & 2.82 & 1.27 \\
Urea with Nutrisphere-N & 180 & 2.94 & 1.38 \\
Urea with Nutrisphere-N & 270 & 3.01 & 1.44 \\
Spring applied N & & & \\
Urea & 90 & 2.30 & 1.21 \\
Urea & 180 & 2.62 & 1.27 \\
Urea & 270 & 2.68 & 1.33 \\
Urea with Nutrisphere-N & 90 & 2.87 & 1.29 \\
Urea with Nutrisphere-N & 180 & 2.93 & 1.38 \\
Urea with Nutrisphere-N & 270 & 3.00 & 1.41 \\
LSD (0.05) & & 0.09 & 0.05 \\
\hline
\end{tabular}


Pawel Wiatrak and Walter B. Gordon / American Journal of Agricultural and Biological Sciences 9 (1): 89-93, 2014

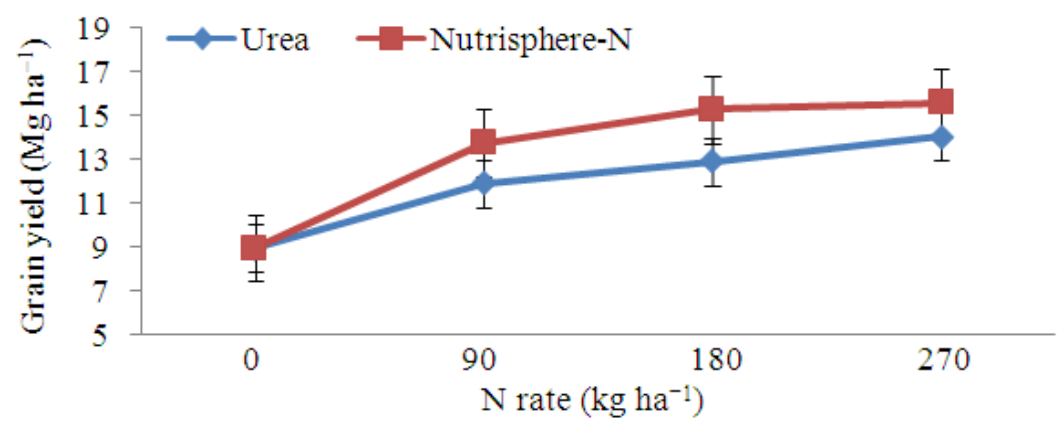

Fig. 1. Influence of $\mathrm{N}$ application rate in the form of urea with Nutrisphere- $\mathrm{N}$ applied in the fall on grain yields of irrigated corn. Vertical bars indicate standard error of four replicates

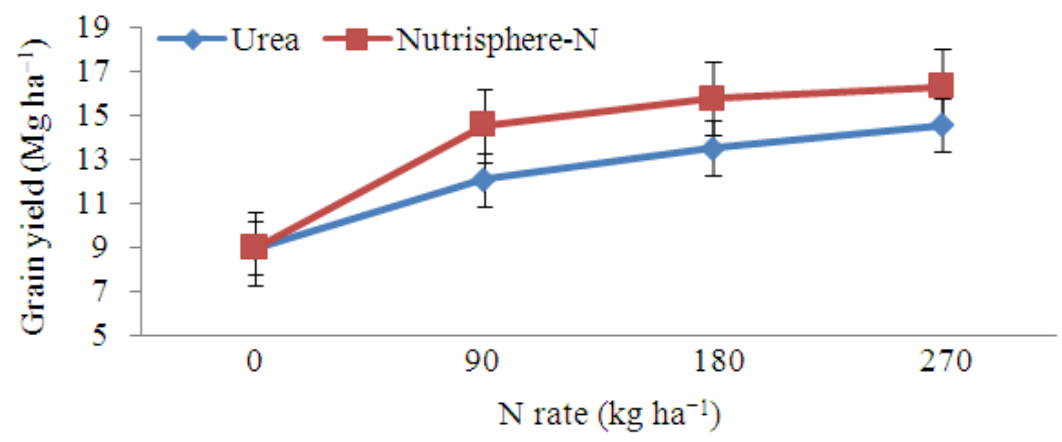

Fig. 2. Influence of $\mathrm{N}$ application rate in the form of urea with Nutrisphere- $\mathrm{N}$ applied in the spring on grain yields of irrigated corn. Vertical bars indicate standard error of four replicates

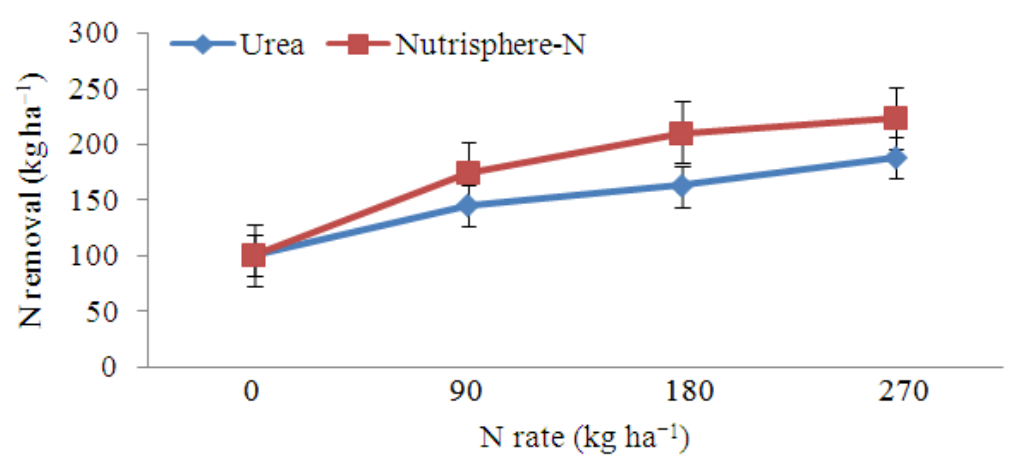

Fig. 3. Influence of $\mathrm{N}$ application rate in the form of urea with Nutrisphere-N applied in the fall on grain $\mathrm{N}$ removal in irrigated corn. Vertical bars indicate standard error of four replicates

\subsection{Grain Yields}

Urea coated with Nutrisphere-N improved corn grain yields by $18.3 \%$ at $180 \mathrm{~kg} \mathrm{~N} \mathrm{ha}^{-1}$ applied in the fall over uncoated urea (Fig. 1). With spring $\mathrm{N}$ applications, grain yields were similar for treatments with and without Nutrisphere-N (Fig. 2). Treating urea with Nutrisphere-N, increased corn yields on average by $15 \%$ with fall $\mathrm{N}$ application and $16.3 \%$ with $\mathrm{N}$ applied in the spring.

\subsection{Grain N Removal}

Grain $\mathrm{N}$ removal was greater with higher grain yields and $\mathrm{N}$ content. Urea coated with Nutrisphere-N improved grain $\mathrm{N}$ removal by $29.6 \%$ over uncoated urea at $180 \mathrm{~kg} \mathrm{~N} \mathrm{ha}^{-1}$ applied in the fall (Fig. 3). 


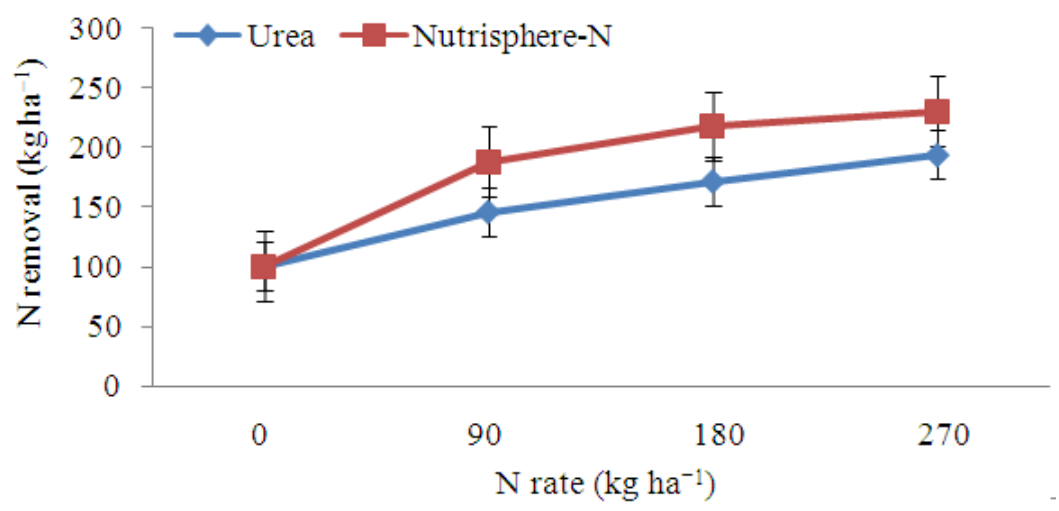

Fig. 4. Influence of $\mathrm{N}$ application rate in the form of urea with Nutrisphere- $\mathrm{N}$ applied in the spring on grain $\mathrm{N}$ removal in irrigated corn. Vertical bars indicate standard error of four replicates

For $\mathrm{N}$ applied in the spring, grain removal was similar for treatments with and without Nutrisphere-N (Fig. 4). On average grain $\mathrm{N}$ recovery improved by more than $20 \%$ with Nutrisphere- $\mathrm{N}$ treated over untreated urea for fall and spring applied $\mathrm{N}$.

\section{DISCUSSION}

Previous research with $\mathrm{N}$ additives has shown significant amounts of variation. Slow-release N products did not provide advantage over conventional fertilizer in bell pepper (Capsicum annuиm L.) production (Stagnari and Pisante, 2012) and Nutrisphere$\mathrm{N}$ reportedly did not affect spring wheat and rice yields (Franzen et al., 2011).

However, unpublished replicated studies with rice over a six year period showed consistent Nutrisphere-N responses (personal communication, Dr. R. Helms, G\&H Associates, Stuttgart, AR). Gordon (2008) reported consistent and highly significant effects of Nutrisphere-N on irrigated corn and dryland grain sorghum responses to $\mathrm{N}$ over a 2 year period in Kansas. Mooso et al. (2012) reported that Nutrisphere-N significantly increased dryland wheat yields in the Northern Great Plains (Montana) particularly at the lower $\mathrm{N}$ rates examined. Murphy and Sanders (2007) cited a number of studies with positive responses to Nutrisphere-N effects on $\mathrm{N}$ management. Polymer-coated urea (slow solubility) helped to reduce $\mathrm{NO}_{3}-\mathrm{N}$ leaching in potato (Solanum tuberosum L.) (Wilson et al., 2009). Greater $\mathrm{N}$ recovery was reported from coated than regular fertilizer due to better timing in releasing $\mathrm{N}$ and matching crop $\mathrm{N}$ demand (Wen et al., 2001). Drury et al. (2012) observed that polymer-coated urea was very effective with high soil moisture and resulted in reduced $\mathrm{N}_{2} \mathrm{O}$ emissions.
Moreover, slow release products reduced nutrient losses and improved water use efficiency under insufficient rainfall (Ni et al., 2011).

This study showed that compared to control, urea coated with Nutrisphere- $\mathrm{N}$ applied in the fall improved corn grain yields by $18.3 \%$ at $180 \mathrm{~kg} \mathrm{~N}^{-1}$, but spring $\mathrm{N}$ application with polymer produced similar yields compared to urea without Nutrisphere-N. Nutrisphere-N improved corn ear-leaf, which was highest at 180 and $270 \mathrm{~kg} \mathrm{~N} \mathrm{ha}^{-1}$ applied in the fall and spring and also high with urea applied at $90 \mathrm{~kg} \mathrm{~N}^{-1}$ in the fall. Grain $\mathrm{N}$ content improved significantly at $240 \mathrm{~kg} \mathrm{~N}$ ha $^{-1}$ applied in the fall and spring. Urea applied with Nutrisphere-N in the fall increased grain $\mathrm{N}$ removal by $29.6 \%$ over uncoated urea, but spring applications showed similar grain $\mathrm{N}$ removal for treatments with and without Nutrisphere-N applications.

\section{CONCLUSION}

This study investigated the effect of two $\mathrm{N}$ application timings (fall and spring) and four $\mathrm{N}$ application rates $\left(0,90,180\right.$ and $\left.270 \mathrm{~kg} \mathrm{~N}^{-1}\right)$ with Nutrisphere-N polymer on earl-leaf $\mathrm{N}$ content, grain yield, grain $\mathrm{N}$ content and $\mathrm{N}$ removal. Compared to untreated N, Nutrisphere-N significantly improved corn ear-leaf content. Highest content was observed from urea with Nutrisphere-N applications at 180 and $270 \mathrm{~kg} \mathrm{~N}$ $\mathrm{ha}^{-1}$ applied in the fall and spring and also for urea at 90 $\mathrm{kg} \mathrm{N}^{-1}$ applied in the fall. Corn grain yields improved with urea coated with Nutrisphere-N by $18.3 \%$ at $180 \mathrm{~N}$ $\mathrm{ha}^{-1}$ applied in the fall, but produced yields were similar for urea with and without Nutrisphere-N applied in the spring. Nutrisphere- $\mathrm{N}$ increased grain $\mathrm{N}$ content, which was highest at $270 \mathrm{~kg} \mathrm{~N} \mathrm{ha}^{-1}$ applied in the fall and spring. Grain $\mathrm{N}$ removal was $29.6 \%$ 
greater with application of Nutrisphere-N over uncoated urea at $180 \mathrm{~kg} \mathrm{~N} \mathrm{ha}^{-1}$ in the fall. Spring urea application with Nutrisphere-N showed similar $\mathrm{N}$ removal compared to untreated urea. Future research may focus on evaluating soil $\mathrm{N}$ transformations and availability to crops under different soil moisture conditions during the growing season.

\section{ACKNOWLEDGEMENT}

Researchers greatly appreciate financial support from Specialty Fertilizer Products (SFP) for conducting field research.

\section{REFERENCES}

Anthony, P., G. Malzer, M.C. Zhang and S. Sparrow, 2012. Soil nitrogen and phosphorus behavior in a long-term fertilization experiment. Agron. J., 104: 1223-1237. DOI: 10.2134/agronj2012.0020

Cahill, S., D. Osmond, R. Weisz and R. Heiniger, 2010. Evaluation of alternative nitrogen fertilizers for corn and winter wheat production. Agron. J., 102: 12261236. DOI: 10.2134/agronj2010.0095

Drury, C.F., W.D. Reynolds, X.M. Yang, N.B. McLaughlin and T.W. Welacky et al., 2012. Nitrogen source, application time and tillage effects on soil nitrous oxide emissions and corn grain yields. Soil Sci. Soc. Am. J., 76: 1268-1279. DOI: 10.2136/sssaj2011.0249

Franzen, D., R.J. Goos, R.J. Norman, T.W. Walker and T.L. Roberts et al., 2011. Field and laboratory studies comparing Nutrisphere-nitrogen urea with urea in North Dakota, Arkansas and Mississippi. J. Plant Nutr., 34: 1198-1222. DOI: 0.1080/01904167.2011.558162

Gordon, W.B., 2008. Nitrogen management for notillage corn and grain sorghum production. International Plant Nutrient Institute.

Hubbard, R.K., J.M. Sheridan, R. Lowrance, D.D. Bosch and G. Vellidis, 2004. Fate of nitrogen from agriculture in the southeastern coastal plain. J. Soil Water Cons., 59: 72-86.

Kyveryga, P.M., P.C. Caragea, M.S. Kaiser and T.M. Blackmer, 2013. Predicting risk from reducing nitrogen fertilization using hierarchical models and on-farm data. Agron. J., 105: 85-94. DOI: 10.2134/agronj2012.0218

Martinez-Alcantara, B., A. Quinones, M.A. FornerGiner, D.J. Iglesias and E. Primo-Millo et al., 2012. Impact of fertilizer-water management on nitrogen use efficiency and potential nitrate leaching in citrus trees. Soil Sci. Plant Nutr., 58: 659-669. DOI: 10.1080/00380768.2012.733678
Mooso, G.D., T.A. Tindall, G. Jackson and H. Zhang, 2012. Increasing the efficiency of MAP and urea applied to winter wheat in Montana with Avail and Nutrisphere-N. Proc. Great Plains Soil Fertility Conf., 14: 209-214.

Mortvedt, J.J., L.S. Murphy and R.H. Follett, 1999. In Fertilizer Technology and Application, Chapter 2, Fertilizer Nitrogen. 1st Edn., Meister Publishing Co., Willoughby, OH, pp: 32.

Murphy, L. and L. Sanders, 2007. Improving N and P use efficiency with polymer technology. Proceedings of the Indiana CCA Annual Training Meeting, Indianapolis, IN, Dec. 18-19, Purdue University, Division of Continuing Education, pp: 1-13.

Ni, B.L., M.Z. Liu and S.Y. Lu, 2009. Multifunctional slow-release urea fertilizer from ethylcellulose and superabsorbent coated formulations. Chem. Eng. J., 155: 892-898. DOI: 10.1016/j.cej.2009.08.025

Ni, B.L., M.Z. Liu, S.Y. Lu, L.H. Xie and Y.F. Wang, 2011. Environmentally friendly slow-release nitrogen fertilizer. J. Agric. Food Chem., 59: 1016910175. DOI: $10.1021 / \mathrm{jf} 202131 \mathrm{z}$

SAS, 2011. SAS/STAT® 9.3 User's Guide. SAS Institute Inc., Cary, NC.

Shaviv, A., 2005. Environmental friendly nitrogen fertilization. Sci. China Series C-Life Sci., 48: 937947. DOI: $10.1360 / 062005-285$

Spargo, J.T., M.A. Cavigelli, S.B. Mirsky, J.E. Maul and J.J. Meisinger, 2011. Mineralizable soil nitrogen and labile soil organic matter in diverse long-term cropping systems. 90: 253-266. DOI: 10.1007/s10705-011-9426-4

Stagnari, F. and M. Pisante, 2012. Slow release and conventional $\mathrm{N}$ fertilizers for nutrition of bell pepper. Plant Soil Environ., 58: 268-274.

Wen, G., T. Mori, T. Yamamoto, J. Chikushi and M. Inoue, 2001. Nitrogen recovery of coated fertilizers and influence on peanut seed quality for peanut plants grown in sandy soil. Commun. Soil Sci. Plant Anal., 32: 3121-3140. DOI: 10.1081/css-120001111

Wilson, M.L., C.J. Rosen and J.F. Moncrief, 2009. Potato response to a polymer-coated urea on an irrigated, coarse-textured soil. Agron. J., 101: 897905. DOI: 10.2134/agronj2008.0192x 